\title{
Ochrona dobrego imienia Józefa Piłsudskiego w świetle przepisów prawa karnego oraz w praktyce sądowej w okresie II Rzeczypospolitej
}

We współczesnej literaturze historycznoprawnej i historycznej dość dobrze opracowano i przeanalizowano praktykę orzeczniczą Sądu Najwyższego w zakresie ochrony czci marszałka Józefa Piłsudskiego, szczególnie po wejściu w życie kodeksu karnego z 1932 roku$^{1}$. Istnieją także publikacje o charakterze popularnonaukowym i pamiętnikarskim odnoszące się przynajmniej w części do kwestii ochrony czci Józefa Piłsudskiego ${ }^{2}$. Brakuje natomiast opracowań odwołujących się do orzecznictwa sądów niższych instancji. Także praktyka orzecznicza sądów wojskowych w tym zakresie nie była dotychczas przedmiotem szerszej analizy historycznoprawnej.

Józef Piłsudski należy niewątpliwie do najbardziej znaczących postaci w historii Polski XX wieku. W latach 1918-1922 roku sprawował funkcję Naczelnika Państwa, dwukrotnie funkcję premiera, wielokrotnie od 1926 roku piastował sta-

${ }^{1}$ Por. przede wszystkim A. Bojańczyk, Karnoprawna ochrona czci i dobrego imienia Józefa Pitsudskiego w latach 30-tych XX wieku cz. 1, „Palestra” 2006, nr 3-4, s. 157-164 oraz idem, Karnoprawna ochrona czci i dobrego imienia Józefa Pitsudskiego w latach 30-tych XX wieku, cz. 2, „Palestra” 2006, nr 5-6, s. 226-234. Pewne aspekty związane z prawnokarną ochroną czci i dobrego imienia Józefa Piłsudskiego porusza również P. Kusiak, Legenda i kult Józefa Piłsudskiego. Jak w Polsce doby integracji europejskiej interpretować postać Marszałka? „Colloquium Wydziału Nauk Humanistycznych i Społecznych” 2010, nr 11, s. 241-258. Warto również przywołać pracę M. Urbańczyka, Ochrona czci i godności narodu w polskiej kulturze prawnej [w:] A. Sylwestrzak, D. Szpoper, A. Michnikowska, P. Dąbrowski (red.), Kultura i Myśl Polityczno-Prawna, Kraków 2010, s. 505-515.

2 Por. M. Urbanek, Polska jest jak obwarzanek, Wrocław 1988, M. Romeyko, Przed i po maju, Warszawa 1967, sprawę S. Cywińskiego, oskarżonego o uwłaczanie czci Marszałka opisuje także S. Glaser w swych wspomnieniach, por. S. Glaser, Urywki wspomnień, Londyn 1974. 
nowisko ministra spraw wojskowych, od 1926 roku aż do śmierci był Generalnym Inspektorem Sił Zbrojnych. Od zarania niepodległości państwa polskiego pełnił zatem istotne funkcje państwowe.

Ochrona prawnokarna dobrego imienia Piłsudskiego wiązała się przede wszystkim z piastowaniem przez niego funkcji Naczelnika Państwa, najwyższego urzędu państwowego. Pierwotnie czyny godzące w dobre imię Naczelnika kwalifikowano odpowiednio jako przestępstwa z art. 128 k.k. z 1903 roku (tzw. kodeksu karnego Tagancewa), zgodnie z którym przestępstwem było „okazanie zuchwałego nieposzanowania władzy zwierzchniej lub ganienia ustalonej przez ustawy formy rządu (...) przez wygłoszenie albo odczytanie publiczne mowy lub utworu albo przez rozpowszechnienie lub publiczne wystawienie utworu lub wizerunku"3.

Przykładem stosowania przywołanego powyżej przepisu (pierwotnie odnoszącego się do władz carskich) w niepodległej Polsce była sprawa Andrzeja Niemojewskiego, podejrzewanego o „zuchwałą zniewagę Naczelnika Państwa"4. Podejrzany w dniach 28 listopada 1918 roku i 1 grudnia 1918 roku miał określić Naczelnika mianem „bandyty politycznego i szalbierza". Prokurator Sądu Apelacyjnego w Warszawie przesyłając ministrowi sprawiedliwości akta analizowanej sprawy podkreślił, że dotychczasową praktyką było, iż ściąganie osób podejrzanych o popełnienie przestępstwa z art. 128 k.k. z 1903 roku odbywało się zawsze za zgodą władzy zwierzchniej, której obraza dotyczyła ${ }^{6}$. Z tego też względu akta sprawy przekazano do Kancelarii Cywilnej Naczelnika Państwa z prośbą o udzielenie wskazówek czy należy wszcząć postępowanie karne w tej sprawie ${ }^{7}$.

W odpowiedzi do ministerstwa sprawiedliwości przekazano informację, iż Naczelnik Państwa postanowił, aby postępowania karnego wobec Andrzeja Niemojewskiego w sprawie o obrazę władzy nie wszczynać ${ }^{8}$. Podobną praktykę stosowano również w innych sprawach o obrazę czci Naczelnika Państwa. Józef Piłsudski nie wyraził zgody m.in. na pociągniecie do odpowiedzialności redaktorów „Gazety Porannej 2 grosze”, którzy w numerze z 11 stycznia 1920 roku zamieścili

3 Kodeks karny z 1903 r., z uwzględnieniem uzupełnień i zmian obowiązujących w Rzeczypospolitej Polskiej w dniu 1 maja 1921 r., Warszawa 1922, s. 49-50.

${ }^{4}$ Archiwum Akt Nowych [dalej AAN] Kancelaria Cywilna Naczelnika Państwa, AAN sygn. akt 2/3/0/1.4/11, k. 4 .

${ }^{5}$ Pismo Prokuratora Sądu Apelacyjnego w Warszawie do Ministra Sprawiedliwości z dnia 28 grudnia 1918 roku, sygn. akt 2/3/0/1.4/11, k. 3.

${ }^{6}$ Ibidem.

7 Pismo ministra sprawiedliwości do Kancelarii Cywilnej Naczelnika Państwa z 31 grudnia 1918 roku, AAN sygn. akt 2/3/0/1.4/11, k. 2.

${ }^{8}$ Notatka w aktach sprawy, AAN sygn. akt 2/3/0/1.4/11, k. 2. 


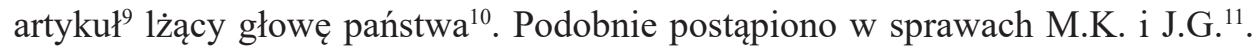
Żadnych konsekwencji za publiczne stwierdzenie, że „Naczelnik Państwa Piłsudski to taki sam złodziej jak i wy legioniści ${ }^{12}$ ", nie poniosła L.K., żona rejenta i właścicielka folwarku. Również w tej sprawie Józef Piłsudski nie wyraził zgodny na pociągnięcie podejrzewanej do odpowiedzialności karnej.

Rozporządzeniem Rady Ochrony Państwa z dnia 17 września 1920 roku w przedmiocie kar za obrazę Naczelnika Państwa ${ }^{13}$ spenalizowano zachowania godzące bezpośrednio w cześć i dobre imię Naczelnika Państwa. Jako znamiona wspomnianego powyżej typu czynu zabronionego wskazano działanie poprzez obrazę Naczelnika za pomocą uwłaczających jego czci mów, okrzyków, gróźb lub zachowania się w urzędach, miejscach i zebraniach publicznych, a także poprzez uwłaczające czci pisma, afisze, druki, obrazy, wizerunki, rysunku lub utwory wprowadzane do obiegu, rozpowszechnianie lub wystawiane na widok publiczny.

Występek ten był zagrożony karą więzienia do 3 lat i karą grzywny bądź alternatywnie jedną z tych kar. Rozporządzenie powyższe obowiązywało niewiele ponad 3 miesiące, albowiem zostało uchylone ustawą z dnia 17 grudnia 1920 roku uchylającą rozporządzenie Rady Ochrony Państwa z dnia 17 września 1920 roku w przedmiocie kar za obrazę Naczelnika Państwa ${ }^{14}$. W artykule 2 wskazano, że ustawa uchylająca rozporządzenie wchodzi w życie z dniem jej ogłoszenia, co nastąpiło 21 stycznia 1921 roku. W związku z tak krótkim okresem obowiązywania rozporządzania nie wytworzyła się żadna szczególna praktyka orzecznicza w zakresie stosowania przepisu przewidującego omawiany występek.

Wraz z wejściem w życie rozporządzenia prezydenta z 11 lipca 1932 roku kodeks karny do ochrony dobrego imienia i czci Józefa Piłsudskiego stosowano przepisy tego właśnie aktu prawnego. Wprawdzie kodeks karny nie zawierał żadnej szczegółowej dyspozycji ustawowej odnoszącej się do osoby Marszałka, jednakże dość powszechną praktyką orzeczniczą było stosowanie per analogiam

9 Był to tekst pt. „Zbawczyni Naczelnika Państwa” opisujący, jak niejaka Khonowa uratowała życie Józefowi Piłsudskiemu po jednej z akcji ekspropriacyjnych PPS w 1906 r. przebierając go za kobietę. Khonowa miała za okazaną pomoc zostać zesłana na Syberię, natomiast po powrocie ze zsyłki w 1918 roku otrzymać od Naczelnika Państwa, w dowód wdzięczności, licencję na prowadzenie szynku w okolicach Łodzi, por. Zbawczyni Naczelnika Państwa, „Gazeta Poranna 2 grosze”, nr 11, r. 1920, s. 7-8.

${ }^{10}$ Pismo Szefa Kancelarii Cywilnej Naczelnika Państwa do Ministra Sprawiedliwości z 7 lutego 1920 roku, AAN sygn. akt 2/3/0/1.4/11, k. 21.

${ }^{11}$ Pismo Szefa Kancelarii Cywilnej Naczelnika Państwa do Ministra Sprawiedliwości z 15 lutego 1920 roku, AAN sygn. akt 2/3/0/1.4/11, k. 23.

12 Pismo skierowane do Kancelarii Cywilnej Naczelnika Państwa, AAN sygn. akt 2/3/0/1.4/11, k. 30 .

13 Dz.U. z 1920 r. nr 91 poz. 598.

${ }_{14}$ Dz.U. z 1921 r. nr 3 poz. 7. 
przepisu art. 152 k.k. penalizującego lżenie lub wyszydzanie narodu albo państwa polskiego ${ }^{15}$.

Już w 1934 roku Sąd Najwyższy w orzeczeniu o sygnaturze 281/34 stwierdził, iż „okoliczność, że czyn zawiera również cechy obrazy osobistej, nie wyłącza możliwości równoczesnego istnienia cech zniewagi Narodu Polskiego i istnienia u sprawcy zamiaru, skierowanego na popełnienie zarówno zniewagi osobistej, jako też zniewagi Narodu Polskiego" ${ }^{16}$. Podobne stanowisko wyraził Sąd Najwyższy w wyroku z 5 października 1937 r., sygn. $1 \mathrm{~K}$. 858/37, stwierdzając, iż „zniewagę Narodu lub Państwa Polskiego popełnić można nie tylko przez publiczne użycie słów, bezpośrednio lżących lub wyszydzających Naród lub Państwo Polskie, lecz także przez użycie wyrażeń lżących lub wyszydzających Pierwszego Marszałka Polski śp. Józefa Piłsudskiego" ${ }^{17}$. W uzasadnieniu powyższego wyroku Sąd Najwyższy wskazał, że „wyrażenia się inkryminowane oskarżonego o Marszałku Piłsudskim w sposób pośredni również lżą i wyszydzają Naród i Państwo Polskie, które Józefa Piłsudskiego czczą powszechnie jako symbol cnót Narodu"18. Stanowisko wyrażone przez Sąd Najwyższy w przywołanym powyżej orzeczeniu jest współcześnie krytykowane i przedstawiane jako przykład stosowania niedozwolonej co do zasady analogii w prawie karnym ${ }^{19}$.

Bez wątpienia najgłośniejszą sprawą dotyczącą ochrony czci i dobrego imienia Józefa Piłsudskiego była sprawa Stanisława Cywińskiego, docenta Uniwersytetu Stefana Batorego w Wilnie. Cywiński w recenzji książki Melchiora Wańkowicza opublikowanej na łamach „Dziennika Wileńskiego” miał stwierdzić, że „Wańkowicz (...) zadaje kłam słowom pewnego kabotyna, który mawiał o Polsce, że jest jak obwarzanek: tylko to coś warte, co jest po brzegach, a w środku pustka ${ }^{20 "}$.

W kilkanaście dni po publikacji Cywińskiego ukazał się na łamach tygodnika „Naród i Państwo” anonimowy artykuł „Plugastwo słowa”, w którym autor wskazał, że Cywiński pisząc o „kabotynie” miał na myśli Józefa Piłsudskiego ${ }^{21}$. Autorstwo tego tekstu powszechnie przypisywano Wańkowiczowi, który jednak

${ }^{15}$ A. Bojańczyk, Karnoprawna ochrona czci i dobrego imienia...cz.2, s. 229.

16 Za: L. Peiper, Komentarz do kodeksu karnego, prawa o wykroczeniach, przepisów wprowadzających obie te ustawy oraz do rozporzadzenia Prezydenta R.P. o niektórych przestępstwach przeciw bezpieczeństwu Państwa z dnia 24 października 1934 roku (Dz.U. Nr 94, poz 851., z uwzględnieniem ustawy karnej skarbowej, ordynacji podatkowej, kodeksu karnego wojskowego, ustaw dodatkowych, orzecznictwa Sąu najwyższego, Kraków 1936, s. 325.

17 Zbiór Orzeczeń SN, z. III/1938, poz.63, s. 130-131.

${ }^{18}$ Ibidem.

19 A. Bojańczyk, Karnoprawna ochrona czci i dobrego imienia ...cz.2, s. 230, także: M. Urbańczyk, Ochrona czci i godności narodu..., s. 511.

${ }^{20}$ S. Cywiński, C.O.P., „Dziennik Wileński” 1938, nr 29, s. 3.

${ }^{21}$ S. Glaser, Urywki..., s. 61-62. 
zdecydowanie temu zaprzeczał. Nie budzi jednak wątpliwości, że publikacja na łamach „Narodu i Państwa” miała charakter denuncjacji i wywołała niekorzystne dla Cywińskiego skutki.

Informacja o rzekomym zelżeniu przez Cywińskiego Józefa Piłsudskiego spotkała się bowiem z brutalną reakcją oficerów wileńskiego garnizonu. Inspektor armii w Wilnie generał Stefan Dąb-Biernacki nakazał im złożenie wizyty zarówno w prywatnym mieszkaniu Cywińskiego, jak i w redakcji „Dziennika Wileńskiego"22. W konsekwencji tych wizyt Cywiński, a także dziennikarze „Dziennika Wileńskiego” zostali dotkliwie pobici przez działających w obronie czci Marszałka oficerów ${ }^{23}$. Uczestniczący w pobiciu Cywińskiego i dziennikarzy oficerowie nie ponieśli żadnych konsekwencji swojego działania, a gen. S. Dąb-Biernacki planował wystosować specjalne pismo z podziękowaniami dla oficerów za dobre wykonanie rozkazu, od czego odwiódł go płk Tomasz Obertyński ${ }^{24}$.

Do odpowiedzialności karnej pociągnięto natomiast Stanisława Cywińskiego oraz Aleksandra Zwierzyńskiego, redaktora naczelnego „Dziennika Wileńskiego”, byłego wicemarszałka sejmu. Oskarżono ich o lżenie narodu i państwa polskiego, a więc o czyn z art. 152 k.k. ${ }^{25}$. Obrońcami Cywińskiego zostali Stefan Glaser i Zbigniew Jasiński ${ }^{26}$. Sąd Najwyższy powołując się na konieczność zapewnienia prawidłowego funkcjonowania wymiaru sprawiedliwości przekazał tę sprawę do rozpoznania Sądowi Okręgowemu w Warszawie ${ }^{27}$. W literaturze wskazuje się, że przeniesienie sprawy Cywińskiego z Wilna do Warszawy było spowodowane wzburzeniem mieszkańców miasta z powodu pobicia Cywińskiego i redaktorów „Dziennika Wileńskiego” przez oficerów ${ }^{28}$. W pierwszej instancji warszawski sąd okręgowy skazał Cywińskiego na karę trzech lat więzienia, uniewinnił natomiast Zwierzyńskiego.

Orzeczenie wobec Cywińskiego tak surowej kary spotkało się z reakcją znamienitych postaci ówczesnego świata naukowego. List do marszałka Edwarda Rydza-Śmigłego w obronie oskarżonego wystosował były rektor Uniwersytetu Stefana Batorego w Wilnie prof. Marian Zdziechowski. Odnosząc się do rozprawy przed Sądem Okręgowym w Warszawie Zdziechowski podkreślił: „Nigdy w życiu nie doznałem wrażenia tak gnębiącego, zdawało mi się, że słyszę preludium do przyszłych bolszewickich sądów w Polsce. Wszak bolszewików nie potrzebujemy szukać aż w Moskwie; mamy ich, tych duchowych synów Dzierżyń-

\footnotetext{
${ }^{22}$ M. Romeyko, Przed i po..., s. 612.

${ }^{23}$ M. Urbanek, Polska jest jak..., s. 35-36.

${ }^{24}$ M. Romeyko, Przed i po..., s. 613.

25 „Gazeta Sądowa Warszawska” 1938, nr 27-28, s. 422.

${ }^{26}$ M. Urbanek, Polska jest jak..., s. 67.

${ }^{27}$ S. Glaser, Urywki ..., s. 65.

${ }^{28}$ Ibidem, s. 65.
} 
skiego, w dostatecznej ilości w Polsce"29. Jednocześnie Zdziechowski apelował do marszałka Rydza-Śmigłego o zmianę stosowanego wobec Cywińskiego środka zapobiegawczego i zwolnienie go $\mathrm{z}$ aresztu ${ }^{30}$.

Po wniesieniu apelacji przez obrońców Cywińskiego oraz przez prokuratora w odniesieniu do oskarżonego Zwierzyńskiego Sąd Apelacyjny w Warszawie w wyroku z dnia 4 czerwca 1938 roku, sygn. akt 1 K.A. 481/38 zmienił zaskarżony wyrok w ten sposób, że wobec oskarżonego Cywińskiego orzekł karę 1 roku i 6 miesięcy pozbawienia wolności, natomiast w pozostałym zakresie zaskarżony wyrok utrzymał w mocy ${ }^{31}$.

Uzasadniając swoje stanowisko warszawski sąd apelacyjny podał, że „rozumiał dobrze oskarżony Cywiński, że zelżenie ś.p. Marszałka Piłsudskiego, którego naród ukochał i na ołtarze swojej chwały i dumy narodowej wyniósł, uderzyć musi dotkliwie i boleśnie w uczucia i cześć narodu. Nie podziela Sąd Apelacyjny twierdzenia, zawartego w wywodzie apelacji oskarżonego Cywińskiego, że zniewaga narodu, przewidziana w art. 152 k.k. może być dokonana jedynie bezpośrednio. Sąd Apelacyjny nie identyfikuje Osoby ś.p. Marszałka Piłsudskiego z narodem jako całością, jest zdania, że zniewagi narodu dopuszcza się i ten, kto godzi w najgłębsze uczucia narodu i boleśnie je dotyka. Kto obraża najświętsze uczucia narodu, obraża tym samym i naród" ${ }^{\prime 2}$.

Warto zwrócić uwagę, że w przywołanym fragmencie uzasadnienia wyroku Sąd Apelacyjny dostrzegł problem, jaki stanowiło przypisywanie odpowiedzialności karnej za znieważenie narodu poprzez zniewagę jednostki. Przedmiotem ochrony przepisu art. 152 k.k. z 1932 roku był bowiem naród w sensie politycznym bądź państwo polskie, w tym także jego instytucje ${ }^{33}$. Kodeks natomiast nie zawierał żadnych szczególnych przepisów chroniących dobre imię marszałka Piłsudskiego. Z tego też względu warszawski sąd apelacyjny zastosował dość interesującą interpretację wskazując, że Józef Piłsudski w istocie stał się częścią pamięci zbiorowej narodu, obiektem jego głębokich uczuć, a więc w konsekwencji lżąc „dobrą pamięć narodu” oskarżony godził w jego cześć.

$\mathrm{Z}$ apelem do Aleksandry Piłsudskiej o złożenie wniosku do prezydenta w przedmiocie ułaskawienia Cywińskiego zwrócił się także Władysław Studnicki ${ }^{34}$. Podkreślił, że Józef Piłsudski nigdy nie dopuściłby do ścigania i skazania za zniewagę

${ }^{29}$ Odpis listu b. rektora USB prof. Mariana Zdziechowskiego do marszałka E. Rydza-Śmigłego w sprawie doc. Cywińskiego, Archiwum Akt Nowych, sygn. akt 2/1238/0/4/22, k. 1.

${ }^{30}$ Ibidem, k. 2.

31 „Gazeta Sądowa Warszawska”, r. 1938, nr 27-28, s. 422.

32 Ibidem, s. 423.

33 J. Makarewicz. Kodeks karny. Komentarz, Wyd. V, Lwów 1938, s. 402 i 405.

${ }^{34}$ Odpis listu W. Studnickiego do A. Piłsudskiej z 14 kwietnia 1938, AAN, sygn. akt 2/1238/0/4/22, k. 5. 
swojego imienia, albowiem „on czuł się na to zbyt wielki, by mogły go obrazić [znieważające słowa - K.S.], on czuł się zbyt wspaniałomyślny, aby móc się mścié"35.

Od przywołanego powyżej wyroku warszawskiego sądu apelacyjnego wniesiono kasację. Obrońca Cywińskiego S. Glaser wystąpił z prośbą do wszystkich dziekanów rad adwokackich o podpisanie wraz z nim skargi kasacyjnej, na co przystali ${ }^{36}$. Głównym zarzutem sformułowanym w kasacji było twierdzenie, iż przez obrazę jednostki nie można dopuścić się obrazy narodu ${ }^{37}$. Sąd Najwyższy rozpoznał kasację w dniu 5 kwietnia 1939 roku. W wyroku wydanym tego samego dnia utrzymał w mocy wyrok Sądu Apelacyjnego w Warszawie.

$\mathrm{Na}$ marginesie warto podkreślić, że po śmierci Marszałka nie było nawet teoretycznej możliwości ścigania sprawców znieważających jego osobę w oparciu o przepis art. 256 k.k. przewidujący prywatnoskargową odpowiedzialność karą za zniewagę, gdyż według ugruntowanego już wówczas poglądu ochrona dobrego imienia zmarłemu nie przysługuje, a obelżywe wyrażenie się o zmarłym może stanowić najwyżej naruszenie czci osób najbliższych zmarłego ${ }^{38}$.

Kontrowersje związane ze stosowaniem rozszerzającej interpretacji art. 152 k.k. doprowadziły do uchwalenia ustawy z dnia 7 kwietnia 1938 roku o ochronie imienia Józefa Piłsudskiego, Pierwszego Marszałka Polski ${ }^{39}$. Uzasadniając na posiedzeniu sejmu w dniu 15 marca 1938 roku potrzebę uchwalenia specjalnego aktu prawnego wprowadzającego prawnokarną ochronę imienia Józefa Piłsudskiego premier Felicjan Sławoj-Składkowski wskazywał, że „Józef Piłsudski stworzył okres bohaterski w życiu Narodu Polskiego, budząc nas ze stuletniego snu niewoli i rzucając do walki o niepodległość i przyszłość Polski. Życie Piłsudskiego to walka o potężną Polskę (...) Syk gadzin, które usiłują zatruć życie Polski po śmierci Wodza stłumić należy siłą, siłą zorganizowaną, siłą legalną"40.

Ustawa za uwłaczanie czci marszałka Józefa Piłsudskiego przewidywała karę 5 lat więzienia. Był to jedyny przepis prawnokarny zawarty w tym krótkim, liczącym zaledwie 4 artykuły, akcie prawnym. Warto podkreślić, że typ czynu zabronionego w art. 2 ustawy był poważnym występkiem, bowiem kara 5 lat więzienia była górną granicą ustawowego zagrożenia przewidywanego przez kodeks karny z 1932 roku dla występków. Nadto dodać należy, że wspomniane przestępstwo $\mathrm{z}$ art. 152 k.k. było zagrożone karą do 3 lat więzienia.

W opisie znamion tego typu czynu zabronionego nie wskazano, że sprawca musi działać publicznie, a więc mógł on wypełnić znamiona omawianego typu

${ }^{35}$ Ibidem, k. 5.

36 S. Glaser, Urywki..., s. 70.

37 Ibidem, s. 71.

38 Ibidem, s. 583.

39 Dz.U. z 1938 r. nr 25 poz. 219.

${ }^{40}$ M. Urbanek, Polska jest jak..., s. 59. 
czynu zabronionego działając także niepublicznie, np. wypowiadając treści uwłaczające czci Józefa Piłsudskiego w trakcie prywatnej rozmowy. Bez wątpienia rozszerzało to granice kryminalizacji tego czynu, a jednocześnie stanowiło rozwiązanie odmienne niż to przyjęte w art. 256 k.k., gdzie warunkiem odpowiedzialności karnej za obrazę pod nieobecność pokrzywdzonego była publiczna działalność sprawcy. Dodać należy, że także przepis art. 152 k.k. wymagał publicznego lżenia lub wyszydzania narodu bądź państwa polskiego.

Projekt ustawy skrytykował w przywołanym już liście do Aleksandry Piłsudskiej W. Studnicki, zaznaczając, że sam fakt przedłożenia sejmowi projektu tej ustawy stanowi działania uwłaczające czci Marszałka, gdyż dowodzi, że jego pamięć w Polsce spotyka się jedynie z niechęcią i nienawiścią, i z tego powodu należy jej bronić za pomocą tak drastycznych środków ${ }^{41}$.

$\mathrm{W}$ art. 1 tego aktu prawnego ustawodawca wskazał motywy, jakimi kierował się wprowadzając szczególną ochronę imienia Józefa Piłsudskiego, podkreślono bowiem, że „pamięć czyn i zasługi Józefa Piłsudskiego - Wskrzesiciela Niepodległości Ojczyzny i Wychowawcy Narodu - po wsze czasy należy do skarbnicy ducha narodowego i pozostaje pod szczególną ochroną prawa"42. Ustawa obowiązywała formalnie do dnia 1 stycznia 1970 roku, kiedy to została uchylona przez art. V przepisów wprowadzających kodeks karny z 1969 roku $^{43}$. W istocie po wrześniu 1939 roku jej przepisy nie były stosowane.

Krótki okres faktycznego stosowania przepisów ustawy spowodował, że nie wykształciła się szersza praktyka orzecznicza w sprawach o występek przewidywany przez art. 2 ustawy ${ }^{44}$. Niemniej pod koniec lat 30 . sprawy tego rodzaju trafiały do sądów okręgowych.

A. Bojańczyk przywołuje w swej pracy pt. Karnoprawna ochrona czci i dobrego imienia Józefa Pitsudskiego w latach 30-tych XX wieku przypadek skazania przez Sąd Okręgowy w Toruniu dwóch dziennikarzy za przestępstwo z art. 2 ustawy ${ }^{45}$. Sprawa dotyczyła Zygmunta Felczaka, redaktora czasopisma „Obrona Ludu”, oraz rysownika Kazimierza Klimczaka. Mieli ono uwłaczać czci Marszałka poprzez publikację na łamach wyżej wspomnianego periodyku prześmiewczego rysunku pod tytułem „Dwaj ludowcy u prezydenta RP”"46.

${ }^{41}$ Odpis listu W. Studnickiego do A. Piłsudskiej z 14 kwietnia 1938, AAN, sygn. akt 2/1238/0/4/22, k. 5 .

42 Ibidem.

${ }^{43}$ Ustawa z 19 kwietnia 1969 roku przepisy wprowadzające kodeks karny, Dz.U. z 1969 r. nr 13 poz. 95 .

${ }^{44}$ A. Bojańczyk, Karnoprawna ochrona czci...cz. 2., s. 234.

45 Ibidem; o sprawie tej wspomina również S. Glaser, Urywki..., s. 65.

${ }^{46}$ Ibidem, s. 234. 
Felczaka skazano na 1,5 roku, natomiast Klimczaka na 8 miesięcy więzie$n^{n i a}{ }^{47}$. Obaj oskarżeni złożyli apelację od powyższego wyroku, Sąd Apelacyjny w Poznaniu po jej rozpoznaniu uniewinnił obu podejrzanych ${ }^{48}$. Dodać należy, że prawdopodobnie nie zachowały się akta sądowe tej sprawy. Nie ma ich bowiem w zespole Sądu Okręgowego w Toruniu w Archiwum Państwowym w Toruniu. Sprawa jest znana zatem jedynie z literatury i relacji prasowych, które przywołuje m.in. M. Urbanek ${ }^{49}$.

W literaturze znana jest również sprawa Józefa Mrukwy, mieszkańca wsi Studzionka koło Pszczyny. Oskarżono go o przestępstwo z art. 2 ustawy o ochronie imienia Józefa Piłsudskiego, Pierwszego Marszałka Polski, gdyż miał opowiedzieć niewybredny dowcip na jego temat ${ }^{50}$. Sprawa była rozpoznawana przez Sąd Okręgowy w Katowicach, jednakże wyrok w niej nie zapadł do 1 września 1939 $\mathrm{roku}^{51}$.

S. Glaser w swych wspomnieniach podaje, że wobec niego i innych autorów skargi kasacyjnej w sprawie Cywińskiego wszczęto postępowanie przygotowawcze $\mathrm{w}$ sprawie o przestępstwo $\mathrm{z}$ art. 2 ustawy, bowiem w treści skargi dopatrzono się realizacji znamion przestępstwa uwłaczania czci Józefa Piłsudskiego ${ }^{52}$. Postępowanie jednak zakończyło się na etapie przesłuchania podejrzanych przez prokuratora, nie skierowano do sądu aktu oskarżenia ${ }^{53}$.

Obok powyżej przytoczonych, znanych dotychczasowej literaturze spraw, w zasobach archiwalnych znajdują się akta spraw innych osób oskarżonych w latach 1938-1939 o popełnienie przestępstwa uwłaczania czci Marszałka przewidywanego przez art. 2 ustawy.

W zasobie archiwalnym Archiwum Państwowego w Suwałkach zachowała się sprawa J.B., oskarżonego o to, że 28 listopada 1938 roku we wsi Pobondzie, w powiecie suwalskim publicznie uwłaczał dobremu imieniu Józefa Piłsudskie$\mathrm{go}^{54}$. W czasie zebrania przedwyborczego do rad gromadzkich miał powiedzieć, że „Marszałek Piłsudski ze swoimi ministrami też wywiózł pieniądze za granicę na majątki" ${ }^{55}$.

Podejrzany nie przyznał się do winy. Sąd Okręgowy w Grodnie wydział zamiejscowy w Suwałkach w wyroku z dnia 12 kwietnia 1939 roku uznał oskar-

47 Ibidem.

${ }^{48}$ M. Urbanek, Polska jest..., s. 97.

${ }^{49}$ Ibidem, s. 96-97.

${ }^{50}$ Ibidem, s. 99.

51 Ibidem.

${ }^{52}$ S. Glaser, Urywki..., s. 73.

${ }_{53}$ Ibidem, s. 73

${ }^{54}$ Akt oskarżenia w sprawie J.B., Archiwum Państwowe w Suwałkach, sygn. akt 208/0/ 04/10785, k. b.p.a.

${ }^{55}$ Ibidem. 
żonego winnym popełnienia przestępstwa $\mathrm{z}$ art. 2 ustawy i skazał J.B. na karę 8 miesięcy więzienia ${ }^{56}$. Uzasadniając swoje stanowisko Sąd Okręgowy w Grodnie wskazał, że „złośliwe i oczerniające pamięć ś.p. Marszałka Józefa Piłsudskiego, a tak odbiegające od rzeczywistości historycznej pomówienie go o niski materializm i wyzyskiwania swego stanowiska w państwie dla gromadzenia majątku i lokowania go w sposób szkodliwy dla interesów gospodarczych kraju, uwłacza Jego imieniu, nadając publicznie wypowiedzianym słowom oskarżonego znamiona występku przewidzianego w art. 2 ustawy z 7 kwietnia 1938 roku o ochronie dobrego imienia Józefa Piłsudskiego" ${ }^{57}$.

W zespole archiwalnym Sądu Okręgowego w Radomiu zachowały się akta dwóch spraw o przestępstwo z art. 2 przywołanej powyżej ustawy. Pierwszą sprawą o przestępstwo z art. 2 ustawy, zachowaną w zasobie Archiwum Państwowego w Radomiu jest sprawa K.J., wędrownego grajka, który przebywając we wsi Wyszyna Fałkowska w gminie Ruda Maleniecka, powiat konecki, miał obelżywie wypowiedzieć się w dniu 24 października 1938 roku o osobie zmarłego Marszał$\mathrm{ka}^{58}$. Wobec podejrzanego nie stosowano tymczasowego aresztowania, objęto go natomiast dozorem policji. Akt oskarżenia wobec podejrzanego K.J. wniesiono do Sądu Okręgowego w Radomiu w dniu 22 listopada 1938 roku. Radomski sąd w wyroku z dnia 21 lutego 1939 roku uznał podejrzanego K.J. winnym popełnienia zarzucanego mu czynu uwłaczania imieniu Józefa Piłsudskiego i skazał na karę 6 miesięcy więzienia, zawieszając jej wykonanie na okres 3 lat ${ }^{59}$. Nie sporządzono uzasadnienia wyroku, zatem najprawdopodobniej skazany ani prokuratura nie wniosła apelacji.

Drugą z nich była sprawa W.G., który w dniu 1 stycznia 1939 roku podczas składania życzeń noworocznych przez członków przemysłowej straży pożarnej właścicielowi fabryki „Kamienna - Jan Witwicki” miał nazwać Józefa Piłsudskiego „zdrajcą i łobuzem” "60. Wobec podejrzanego W.G. w dniu 24 stycznia 1939 roku zastosowano środek zapobiegawczy w postaci tymczasowego aresztowania. W.G. nie przyznawał się do popełnienia zarzucanego mu czynu podkreślając, że nie pamięta swojego wystąpienia, gdyż był pod wpływem alkoholu ${ }^{61}$. Sąd Okręgowy w Radomiu w wyroku z 4 kwietnia 1939 roku uznał oskarżonego winnym popełnienia zarzucanego mu czynu i orzekł wobec niego karę 6 miesięcy więzie-

${ }^{56}$ Wyrok Sądu Okręgowego w Grodnie Wydział Zamiejscowy w Suwałkach z dnia 12 kwietnia 1939 roku, sygn. akt 208/0/04/10785, k. b.p.a.

57 Ibidem.

${ }^{58}$ Akt oskarżenia w sprawie K.J., Archiwum Państwowe w Radomiu, sygn. akt K 281. K. b.p.a.

${ }^{59}$ Wyrok w sprawie K.J., Archiwum Państwowe w Radomiu, sygn. akt K 281. K. b.p.a.

${ }^{60}$ Akt oskarżenia w sprawie W.G., Archiwum Państwowe w Radomiu, sygn. akt K. 309, k. b.p.a.

${ }^{61}$ Ibidem. 
nia, zaliczając na poczet kary okres tymczasowego aresztowania od 24 stycznia 1939 roku do 4 kwietnia 1939 roku $^{62}$. Sąd Okręgowy nie sporządził pisemnego uzasadnienia powyższego wyroku, zatem od wyroku nie wniesiono apelacji.

Do ochrony dobrego imienia Marszałka wykorzystywano również przepisy wojskowego prawa karnego. Celowi temu służył m.in. przepis art. 75 rozporządzenia prezydenta RP z 22 marca 1928 roku w sprawie kodeksu karnego wojskowego ${ }^{63}$. Zgodnie $\mathrm{z}$ tą regulacją ten, kto obraża przełożonego bądź starszego stopniem będzie karany zamknięciem w twierdzy lub w więzieniu na okres nie dłuższy niż dwa lata lub aresztem wojskowym, a w razie obrazy w służbie lub w związku z czynnością służbową - zamknięciem w więzieniu lub w twierdzy na czas nie dłuższy od trzech lat. W ten sam sposób karana była obraza przełożonego, jeżeli dokonano jej za pomocą rozpowszechnienia pism, obrazów, utworów lub wizerunków.

Przykładem takiego postępowania jest sprawa porucznika F.S. rozpoznawana przez Wojskowy Sąd Okręgowy nr VII w Poznaniu. Oficerowi temu zarzucono, że dnia 20 marca 1931 roku w restauracji „Kujawy” miał powiedzieć, iż „Piłsudski w ogóle do Polski nie wróci, a jak wróci to my go nie wpuścimy" ${ }^{64}$, a następnie na uwagę siedzącego obok robotnika, aby nie wyrażał się w ten sposób na temat Marszałka, dodał ,jeżeli byłeś jego żołnierzem, idź do Niego na Maderę"65.

Czyn ten zakwalifikowano jako przestępstwo z art. 75 k.k.w. tj. obrazę przełożonego - Ministra Spraw Wojskowych. Sąd uznał oskarżonego oficera winnym i skazał go na karę jednego miesiąca więzienia. Uzasadniając swoje stanowisko Wojskowy Sąd Okręgowy wskazał, że oskarżony dopuścił się obrazy Marszałka z zamiarem ewentualnym. Sąd podkreślił, że z ustaleń faktycznych wynikało, iż oskarżony od 1913 roku należał do Związku Młodzieży Walki Czynnej i był pozytywnie ustosunkowany do rządów pomajowych.

Powyższy wyrok został zaskarżony do Najwyższego Sądu Wojskowego przez prokuratora wojskowego z uwagi na zbyt łagodną karę. Prokurator podkreślił, że złośliwe uwagi oficera na temat Marszałka mogły prowadzić do fałszywych wniosków na temat dyscypliny w armii ${ }^{66}$. Apelację wniósł również obrońca skazanego. W aktach nie zachował się wyrok Najwyższego Sądu Wojskowego w tej sprawie.

Przepisy prawa karnego wykorzystywane do ochrony dobrego imienia Józefa Piłsudskiego były charakterystyczne dla państwa autorytarnego, jakim bez wątpienia była II Rzeczpospolita. Marszałek Piłsudski jako „Ojciec Republiki” był

${ }^{62}$ Wyrok w sprawie W.G, Archiwum Państwowe w Radomiu, sygn. akt K. 309, k. b.p.a.

${ }^{63}$ Dz.U. z 1928 r. nr 36 poz. 328.

${ }^{64}$ Wyrok Wojskowego Sądu Okręgowego nr VII w Poznaniu z 18 grudnia 1931 r., Archiwum Państwowe w Poznaniu, sygn. akt 53/1100/0/2.1/24.

${ }^{65}$ Ibidem.

${ }^{66}$ Apelacja Prokuratora z 28.12.1931 r., AP w Poznaniu, sygn. akt 53/1100/0/2.1/24. 
niejednokrotnie utożsamiany przez ówczesną judykaturę z państwem polskim, stąd tak dalece posunięta ochrona jego dobrego imienia, również po śmierci. Jak się wydaje, ustawa z dnia 7 kwietnia 1938 roku o ochronie imienia Józefa Piłsudskiego, Pierwszego Marszałka Polski miała służyć przede wszystkim celom politycznym i stanowić swego rodzaju oręż w walce z przeciwnikami politycznymi sanacji. Prawnokarna ochrona dobrego imienia Józefa Piłsudskiego znacząco ograniczała prawo do wolności wypowiedzi i wyrażania poglądów. Przywołana w niniejszym artykule jedynie w skromnym zakresie praktyka sądowa wskazuje, że przepisy ustawy z 7 kwietnia 1938 roku stosowano nawet w błahych przypadkach, gdy „lżenie” osoby Pierwszego Marszałka następowało poprzez żart czy było wynikiem działania sprawcy pod wpływem alkoholu.

\title{
PROTECTION OF JÓZEF PIŁSUDSKI'S REPUTATION IN THE LIGHT OF CRIMINAL LAW AND IN THE JUDICIAL PRACTICE IN THE SECOND POLISH REPUBLIC
}

\begin{abstract}
The article analyzes the provisions of criminal law pertaining to the protection of honor and reputation of the Head of State (Polish Naczelnik Państwa). Moreover, the paper considers how the regulations in force applied directly to Józef Piłsudski during the interwar period. The deliberations focus not only on dogmatic considerations. Special attention is also paid to the analysis of the jurisprudence practice of Polish courts in selected criminal cases against perpetrators of defamation of the honor and reputation of Józef Piłsudski.
\end{abstract}

\section{PROTECTION DE LA REPUTATION DE JOZEF PILSUDSKI A LA LUMIERE DU DROIT PENAL ET DE LA PRATIQUE JUDICIAIRE A L'EPOQUE DE LA DEUXIEME REPUBLIQUE DE POLOGNE}

\section{Resumé}

L'auteur analyse les dispositions du droit pénal relatives à la protection de l'honneur et de la réputation du Chef de l'État et concrètement de Józef Piłsudski, qui étaient en vigueur entre les deux guerres. Dans ses délibérations, l'auteur ne se concentre pas uniquement sur des considérations dogmatiques, il analyse également la pratique jurisprudentielle des tribunaux polonais dans certaines poursuites pénales à l'encontre des auteurs des actes portant atteinte à l'honneur et de la réputation de Józef Piłsudski. 